Egyptian Poultry Science Journal

http://www.epsaegypt.com

ISSN: 1110-5623 (Print) - 2090-0570 (On line)

\title{
EFFECT OF SUPPLEMENTING DOUM (HYPHAENE THEBAICA) TO DIETS ON REPRODUCTIVE AND PRODUCTIVE TRAITS IN RABBITS
}

\author{
Mervat, N. Ghazal ${ }^{1}$; Safaa, A. Barakat ${ }^{1}$; Ali, W. A. H. ${ }^{1}$; and Rowida, M. Riad $^{2}$ \\ ${ }^{1}$ Anim. Prod. Res. Insti., Agric. Res. Center, Dokki, Giza, Egypt \\ ${ }^{2}$ Anim. Reprod.Res. Instit., Agric. Res. Center, El-Haram, Giza, Egypt \\ Corresponding author: Mervat Ghazal; Email: mervanabil@ yahoo.com
}

Received: 26/06/2016

Accepted: 19/07/2016

\begin{abstract}
The present work aimed to investigate the effect of supplementing different levels of doum in diets on fertilizing ability of bucks and fertility traits of Hy-Plus rabbit does. The study lasted five months. A total number of 272 Hy-Plus rabbits (64 males aged 3 months and 208 females aged 2.5 months) were used in the present work. Animals were divided into four comparable experimental groups (16 males and 52 females each). The first group was fed a commercial diet and kept untreated (control group), while the $2^{\text {nd }}, 3^{\text {rd }}$ and $4^{\text {th }}$ groups (treated groups) were fed the same diet but supplemented with 250, 500 and $750 \mathrm{~g}$ doum / ton diet, respectively.

Results indicated that, age at first mating of Hy-Plus rabbit males significantly $(\mathrm{p} \leq 0.05)$ decreased, while weight at first mating and live body weight significantly $(p \leq 0.05)$ increased due to fed diets supplemented with different levels of doum. Absolute and relative weights of testes; epididymis; sexual accessory glands and pituitary gland, as well as, scrotal circumference; testicular index and mating activity of Hy-Plus rabbit bucks increased significantly ( $\mathrm{p} \leq 0.05$ or 0.01 ) in descending order with diets supplemented with 750 and $500 \mathrm{~g}$ doum, respectively. Male and female sexual hormones significantly $(\mathrm{p} \leq 0.01)$ increased due to doum supplementation.

Conception and abortion rates, litter size and weight at birth and at weaning, as well as, bunny weight at birth and at weaning were significantly $(\mathrm{p} \leq 0.05$ or 0.01$)$ improved descending by supplementing 750 and $500 \mathrm{~g}$ doum, respectively.

Milk yield and composition and total preweaning mortality rates improved significantly ( $\mathrm{p} \leq 0.05$ or 0.01$)$ by feeding rabbits on diets supplemented with doum.

Conclusively, it could be concluded that, supplementing doum to Hy-Plus rabbit diets caused significant improvement in fertilizing ability of bucks and fertility traits of does. It can be recommended that $500 \mathrm{~g}$ doum/ ton diet gave a good result for rabbits and equal to the high dose.
\end{abstract}

Keywords: rabbit- doum- Hyphaene thebaica- reproductive- fertility- milk. 


\section{INTRODUCTION}

Reproductive aspects of rabbits play an important role in the success and profitability of rabbits breeding. The plane of nutrition given to an animal can affect libido and quality of semen produced (Togun and Egbunike, 2006). It also affects age of attaining puberty and stimulation of the hypothalamus indirectly to produce interstitial cell stimulating hormone that acts in the testicular tissue (Cogan et al., 2004).

Herbal preparations has been applied to boost wide range of primary health care delivery due to biochemical contents of plants in Africa and other parts of the world (Elujoba et al., 2005). Hyphaenethebaica belongs to the family Arecaceae commonly known as doum palm, Dum Nut or gingerbread tree. Roots, fruits and seeds of doum palm are used for the management of jaundice, intestinal colic, hematuria, inguinal hernia bilharzias, hypertension and sore eyes respectively in livestock. And also have been found to possess antioxidant property (Hsu et al., 2006) Phytochemicals are essential elements with protective effect that are required by humans and animals to sustain life. Recent researchers found that Phytochemicals can protect humans against diseases such as hypertension, cancer, diabetes and various forms of microbial infections (Di Carlo et al., 1993).

The level of leucocytes in blood is an important pointer to physiological and pathological status of an individual (Schalm et al., 1975). The concentration of these cells in blood can be increased or decreased by the ingestion of some medicinal plants (Ajagbonn et al., 1999). The unripe kernels of doum are edible; the shoots of germinated seeds are also eaten as a vegetable. Herb tea of doum is popular in Egypt and believed good for hypertension. Research on the fruit pulp has shown that it contains nutritional trace minerals, proteins and fatty acids, particular the nutritionally essential linoleic acid (Cook et al., 2000).
A large number of plants have been screened as a viable source of natural antioxidants including tocopherols, vitamin C, carotenoids and phenolic compounds which are responsible for maintenance of health, and help the body to reduce oxidative damage and protection from coronary heart diseases and cancer (Yang et al., 2002; Kilani et al., 2008). Therefore there is a growing interest in the substances exhibiting antioxidant properties that are supplied to human and animal organisms as food components or a specific pharmaceutica. Hussein et al. (2011) evaluated the chemical composition and physicochemical properties of doum tea infusions. Furthermore, the antioxidant activities of these extracts were investigated by scavenging of 1,1 diphenyl2-picrylehydrozyl (DPPH) radicals. The proliferation inhibition activities on some types of bacteria and yeast were also measured for evaluating the antimicrobial activity of doum tea infusions and their blends. The highest percentage of fiber was found in doum sample. The levels of most elements were high, the highest value of the content of total soluble solids (TSS).

The main objective of the present study was to evaluate some parameters related to reproductive and productive capabilities of Hy-Plus rabbits as influenced by supplementation of doum to the diet.

\section{MATERIALS AND METHODS}

The present study was conducted in an Industrial Rabbitry. The laboratory work was carried out in Animal Production Research Institute, Agriculture Research Center, Dokki, Giza, Egypt.

The ingredients and chemical composition of the pelleted diet to rabbits during experimental period are shown in Table 1 . Composition and chemical analysis of doum used in the experiment are shown in Table 2.

The experimental work

Two hundred and seventy two Hy-Plus rabbits (64 males aged 3 months, and 208 
females aged 2.5 months) were used. Animals in each experiment were divided into four equal comparable experimental groups (16 males and 52 females each). The first group was kept untreated (control group) and fed a commercial diet covering the nutritional requirements of different physiological status of rabbits according to NRC (1977) recommendations, while the $2^{\text {nd }}, 3^{\text {rd }}$ and $4^{\text {th }}$ groups (treated groups) were fed the same diet but supplemented with 250, 500 and $750 \mathrm{~g}$ doum/ ton feed, respectively. The study lasted five months and included two experiments as follow:

First, age and weight of rabbit males at first mating were recorded. At 5 months of age, three bucks from each group were randomly taken for slaughter after being fasted for 12 hours (Abd El-Monem, 1995). After complete bleeding, testes; epididymis; sexual-accessory glands and pituitary gland were weighed and relative weights of those organs were calculated according to the following formulae: relative weight of organ = organ weight/ live body weight $(\mathrm{Fu}-\mathrm{Chang}$ et al., 2004). Scrotal circumference was measured as described by Boiti et al. (2005). Testicular index (length $\times$ width $\times$ depth) was calculated in cubic centimeters as recorded by (Castellini et al., 2006; and El-Kholy et al., 2012).

Mating activity (frequency of mating within 20 minutes) of mature rabbit bucks was determined using sexually receptive does.

Second, experiment aimed to study the effect of supplementing different levels of doum to rabbit diet on fertility traits; milk yield and composition and preweaning mortality rate.

Regarding sexual hormones, during the $5^{\text {th }}$ month of age, blood samples were taken from the marginal ear vein of six rabbit bucks and does per group weekly up to 4 weeks. Blood serum testosterone concentration of bucks and estradiol $17_{2 \alpha}$ and progesterone levels of does were determined using RIA Kits (Immunotech, A Coulter Co., France) according to the manufacturer information. Fertility traits
Natural mating was carried out by transferring each doe to the buck's cage to be mated and return back to its cage after mating. Palpation of all rabbit does was carried out 12 days post mating to determine pregnancy. Conception, abortion, kindling rates and litter size and weight at birth and bunny weight at weaning were recorded. Pre weaning mortality rates and milk yield per doe were estimated also during the suckling period. Milk yield was estimated after deprivation of pups from suckling their mothers at 8 a.m. daily, then the doe and her pups were weighed before and after suckling, the average of decrease and increase in doe and pup's weight, respectively, was used as the doe milk yield.

Milk samples were taken from nursing does individually within each experimental group, on the $21^{\text {st }}$ day of lactating period (peak of milk production). A part of fresh milk sample was immediately analyzed to estimate milk protein, fat, lactose and ash, by using Milkoscan ${ }^{\circledR}$ analyzer-130 B, N. Foss Electronic-Denmark.

\section{Statistical analyses}

Data were subjected to analysis of variance according to (Snedecor and Cochran, 1982) using the General Linear Model Program of SAS (2001). Duncan's new multiple range tests were used to test the significance of the differences among means (Duncan, 1955). Data presented as percentages were transformed to the corresponding arcsine values (Warren and Gregory, 2005) before being statistically analyzed

$\mathrm{Y}_{\mathrm{ij}}=\mu+\alpha_{\mathrm{i}}+\mathrm{e}_{\mathrm{ij}}$

Where: $\quad Y_{i j}=$ Observation of the $j^{\text {th }}$ rabbit in the treatment $i ; \mu=$ Overall mean, common element to all observations; $\alpha_{i}=$ Effect of the treatments ( $i=1,2,3$ and 4); $\mathrm{e}_{\mathrm{ij}}=$ Random error component assumed to be normally distributed.

\section{RESULTS AND DISCUSSION}

\section{Reproductive parameter of bucks}

Data presented in Table 3 indicated that, supplementing doum to Hy-Plus rabbit males diet significantly $(\mathrm{p} \leq 0.05)$ decreased 
their age at first mating compared to control, while weight at first mating significantly $(\mathrm{p} \leq 0.05)$ increased in treatment than control group, respectively. Absolute and relative weights of testes; epididymis; sexual accessory glands and pituitary gland of Hy-Plus rabbit bucks increased significantly $(\mathrm{p} \leq 0.05)$ due to feed diets supplemented with 250,500 and 750 g doum/ ton.

Table 4 showed that, improvement in mating activity; scrotal circumference and testicular index of Hy-Plus rabbit bucks fed diets supplemented with 250, 500 and 750 $\mathrm{g}$ doum were significantly $(\mathrm{p} \leq 0.05$ and 0.01 ) high as compared with those of unsupplemented diets.

\section{Sexual hormones}

Regarding sexual hormones of male and female represented by concentration of testosterone; estradiol $17_{2 \alpha}$ and progesterone, high level of doum recorded a significant $(\mathrm{p} \leq 0.01) \quad$ increase in descending order, due to diet supplemented with 750, 500 and $250 \mathrm{~g}$ doum, respectively (Table 5). These results are in agreement with those obtained by (Mariey et al., 2012).

These improvements in male performance and sexual hormones of treated rabbits may be due to improving of feed utilization as recorded by (Mariey et al., 2012; and Ali and Mervat Ghazal, 2013). Also, dietary inclusion of doum can partially offset the adverse effects of toxins on animal performance. As well as, the results obtained may be due to enhance immune function as a result of adding doum to the diet (Qureshi et al., 1995). This result was due to improved in spermatozoa that showed better results of motility and survivability which can be used as a good indicator of fertilizing ability. Also, emphasized the hypothesis that, rabbits fertility could be improved by stimulation of testicular androgen secretion induced by having diet contained doum, as observed by (Safaa Barakat and Rowida Riad, 2016). This result due to that, doum is a good antioxidants with strong 1, 1 diphenyl-2picrylehydrozyl (DPPH) radicalsscavenging activity, as well as, the investigated extracts had good antimicrobial activity, especially against bacteria (Hussein et al., 1998; SanchezMoreno et al., 1999; and Dawidowicz et al., 2006). Doum is contain certain chemicals which are naturally toxic to bacteria, and many of literature has validated the antimicrobial activity of plant extracts, showing great potential especially against multidrug resistant bacteria (Pesewu et al., 2008; and Tasdelen et al., 2009). Also photochemistry of doum provides insight about phenolic compounds (Katsube et al., 2004; and Dimitrios, 2006). These phenolic compounds often exhibit a wide range of physiological activities that include antioxidant, antimutagenic, anticarcinogenic, antimicrobial, and antiinflammatory properties (Baliga and Katiyar, 2006; and Heinonen, 2007).

\section{Doe traits}

Data presented in Table 6 showed that, Hy-Plus rabbit does fed diets supplemented with 750,500 and $250 \mathrm{~g}$ doum using bucks treated with the same treatment, recorded conception and kindling rates; litter size and weight and bunny weight at birth and at weaning significantly $(\mathrm{p} \leq 0.05$ or 0.01$)$ better, and in descending order, than of those recorded by does fed un-supplemented diet. Also, it can be noticed that doum treatments recorded decrease in abortion and mortality rate than control group. It is apparent clearly from these results that, the fertilizing ability of rabbit semen treated with doum is better than control.

Results in Tables 7 and 8 indicated that, milk yield and composition (protein; fat; lactose and ash) were significantly ( $\mathrm{p} \leq 0.05$ or 0.01$)$ better than control group, and in descending order due to diet supplemented with 750 and 500 then 250 g doum, respectively. 
Finally improving fertility traits of rabbit does treated with doum can be attributed mainly to improve of semen quality, as recorded previously by (Ali and Mervat Ghazal, 2013). In this respect, Lavaraa et al. (2005) observed significant correlations between fertility rate of does and semen quality. Also, it can be due to doum contain $\mathrm{Zn}$, Mn and copper, which have been reported in improving reproduction in males and females.

The improvement in litter traits proved that, doum treatments are capable to improve the milking ability of the rabbit does which is reflected in her ability to suckle her young till weaning, and significant decrease in mortality compared with the control. The milk available per kit may also have a pronounced effect on the mortality of young rabbits (Rommers et al., 2001; and Szendro et al., 2002). Besides that, the increase milk production may be due to increase in litter size at birth, where there was a positive correlation between the litter size at birth and milk yield (Lebas et al., 1997; and Rommers et al., 2001). Does will secrete more milk if litter size at birth is large (EL-Maghawry et al., 1993). This increase in milk production, is however, not entirely proportional to the needs of more suckling. There were a negative correlation between litter size and individual bunny weight. Therefore, one kit consumes less milk and so the individual weight will be low (Petersen et al., 1996). When both litter size and individual weight of suckling rabbits increase this could be only due to the high milk production of the doe. This could be explained our result in increasing the total litter weight and individual weight at birth and weaning and increase milk production in doum treatment than control. This is in agreement with Eiben et al. (2010).

The improvement in bunny survivability can be due to the improvement of does, which secret more milk subsequently the bunny weight and number get better compared to control group. Also improving the survivability can be due to transfer of active material in doum ( $\mathrm{Zn}$, $\mathrm{Mn}$ and copper) which can be used as antioxidant and antimicrobial to the milk of does to the bunny, so the bunny get healthy and its immune system improved and disease resistance increased which reflect on decreasing the mortality rate and improve the fertility rate, litter size and weight and individual weight, even at birth or at weaning. These result agree with that observed by Yang et al. (2002) and Kilani et al. (2008) who reported that doum have been screened as a viable source of natural antioxidants including tocopherols, vitamin $\mathrm{C}$, carotenoids and phenolic compounds which are responsible for maintenance of health, and help the body to reduce oxidative damage and protection from diseases. Therefore, there is a growing interest in the substances exhibiting antioxidant properties that are supplied to human and animal organisms as food components or a specific pharmaceutical.

Conclusively, it could be concluded that: supplementing doum to Hy-Plus rabbit diets caused significant improvement in semen quality, fertilizing ability of bucks, fertility traits and milk yield of does. Also, it can be recommended $500 \mathrm{~g}$ doum/ton diet, where there were no significant differences between the 500 and $750 \mathrm{~g}$ doum / ton. Subsequently there is no need to the high level which increases the productive coast. 
Table (1): The ingredients and chemical composition of the pellet diet fed to growing rabbits, during the experimental period

\begin{tabular}{|c|c|c|c|}
\hline Ingredients & $(\%)$ & \multicolumn{2}{|c|}{$\begin{array}{c}\text { Vitamins \& Minerals premix } \\
\text { per Kilogram. }\end{array}$} \\
\hline Clover hay & 30.00 & Vit.A (IU) & 10,000 \\
\hline Wheat bran & 26.20 & Vit.D3 (IU) & 2000 \\
\hline Barley grain & 23.00 & Vit.E (IU) & 5000 \\
\hline Soybean meal (44\%) & 16.00 & Vit.K (IU) & 2 \\
\hline Molasses & 3.00 & Vit.B1 (IU) & 2 \\
\hline Lime stone & 1.00 & Vit.B2 (IU) & 4 \\
\hline Sodium chloride & 0.50 & Vit.B6 (IU) & 3 \\
\hline Vitamins \& Mineral Premix & 0.30 & Vit.B12 (IU) & 0.02 \\
\hline Total & 100 & Biotin (mg) & 0.2 \\
\hline \multicolumn{2}{|c|}{ Calculated chemical composition $* *$} & Choline (mg) & 1200 \\
\hline Crudeprotein $(\mathrm{CP}) \%$ & 16.72 & Niacine (mg) & 40 \\
\hline Ether extract (EE)\% & 2.95 & $\mathrm{Zn} .(\mathrm{mg})$ & 60 \\
\hline Crude fiber $(\mathrm{CF}) \%$ & 13.07 & Cu. (mg) & 0.1 \\
\hline \multirow[t]{4}{*}{ Digestible energy (Kcal/Kg) } & 2490 & Mn. (mg) & 62 \\
\hline & & Fe. $(\mathrm{mg})$ & 40 \\
\hline & & Folic acid (mg) & 1 \\
\hline & & $\begin{array}{l}\text { Pantothenic acid } \\
(\mathrm{mg})\end{array}$ & 15 \\
\hline
\end{tabular}

** Calculated according to NRC (1977) for rabbits.

Table (2): Composition and chemical analysis of Doum used in the experiment

\begin{tabular}{|l|l|}
\hline \multicolumn{1}{|c|}{ Items } & \multicolumn{1}{c|}{$\%$} \\
\hline Protein & 6.45 \\
Fat & 4.89 \\
Fiber & 11.55 \\
Total carbohydrate & 72.89 \\
Total Sugars & 12.66 \\
Reducing Sugars & 1.99 \\
None Reducing Sugars & 10.67 \\
Elements(mg/100g) & \\
Potassium & 5.99 \\
Calcium & 92.24 \\
Magnesium & 1.31 \\
Iron & 1.95 \\
Copper & 1.82 \\
Zinc & 0.04 \\
Manganese & 0.09 \\
\hline
\end{tabular}

Recorded by (Hussein et al., 2011). 
Table (3): Age and weight at first mating, pituitary and some sexual organs weight of HyPlus rabbit males fed diets supplemented with different levels of Doum (Means \pm SE)

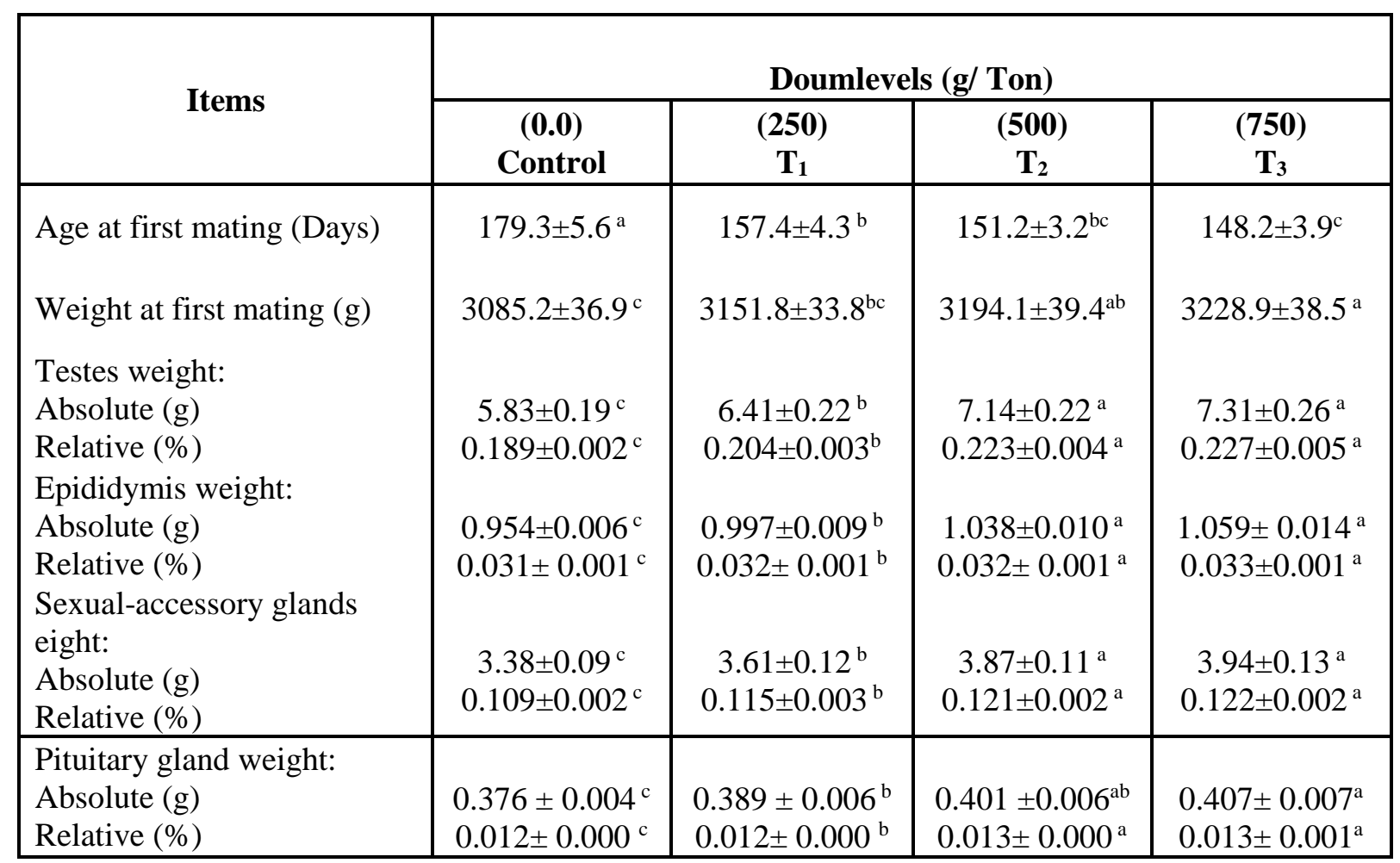

Means bearing different letter superscripts $(a, b, c)$ within the same row are significantly ( $\leq \leq 0.05$ or 0.01 ) different. 
Table (4): Some parameters indicated fertilizing ability of Hy-Plus rabbit males fed diets with different levels of Doum (Means \pm SE)

\begin{tabular}{|l|c|c|c|c|}
\hline \multirow{2}{*}{\multicolumn{1}{|c|}{ Items }} & \multicolumn{4}{|c|}{ Doumlevels (g/ Ton) } \\
\cline { 2 - 5 } & $\begin{array}{c}\mathbf{( 0 . 0 )} \\
\text { Control }\end{array}$ & $\begin{array}{c}\mathbf{( 2 5 0 )} \\
\mathbf{T}_{\mathbf{1}}\end{array}$ & $\begin{array}{c}\mathbf{( 5 0 0 )} \\
\mathbf{T}_{\mathbf{2}}\end{array}$ & $\begin{array}{c}\mathbf{( 7 5 0 )} \\
\mathbf{T}_{\mathbf{3}}\end{array}$ \\
\hline $\begin{array}{l}\text { Mating activity } \\
\text { (no. of mating/ 20 minutes) }\end{array}$ & $2.14 \pm 0.06^{\mathrm{c}}$ & $2.86 \pm 0.05^{\mathrm{b}}$ & $3.09 \pm 0.07^{\mathrm{a}}$ & $3.15 \pm 0.07^{\mathrm{a}}$ \\
Scrotal circumference $(\mathrm{Cm})$ & $6.43 \pm 0.57^{\mathrm{c}}$ & $7.24 \pm 0.63^{\mathrm{bc}}$ & $7.83 \pm 0.79^{\mathrm{ab}}$ & $8.79 \pm 0.77^{\mathrm{a}}$ \\
Testicular index $\left(\mathrm{Cm}^{3}\right)$ & $5.35 \pm 0.38^{\mathrm{c}}$ & $6.19 \pm 0.51^{\mathrm{bc}}$ & $6.69 \pm 0.62^{\mathrm{ab}}$ & $7.46 \pm 0.64^{\mathrm{a}}$ \\
\hline
\end{tabular}

Means bearing different letter superscripts $(a, b, c)$ within the same row are significantly $(p \leq 0.05$ or 0.01 ) different.

Table (5): Sexual hormones concentration of Hy-Plus rabbit males fed diets with different levels of Doum (Means \pm SE)

\begin{tabular}{|c|c|c|c|c|}
\hline \multirow{2}{*}{ Sexual hormo.ne } & \multicolumn{4}{|c|}{ Doumlevels (g/ Ton) } \\
\hline & $\begin{array}{l}(0.0) \\
\text { Control } \\
\end{array}$ & $\begin{array}{l}(250) \\
\mathrm{T}_{1} \\
\end{array}$ & $\begin{array}{c}(\mathbf{5 0 0}) \\
\mathbf{T}_{2} \\
\end{array}$ & $\begin{array}{c}(\mathbf{7 5 0}) \\
\mathbf{T}_{3} \\
\end{array}$ \\
\hline $\begin{array}{l}\text { Testosterone concentration (ng/ } \\
\mathrm{ml} \text { ) }\end{array}$ & $5.62 \pm 0.09^{\mathrm{c}}$ & $5.81 \pm 0.08^{b}$ & $5.98 \pm 0.09^{\mathrm{ab}}$ & $6.04 \pm 0.09^{\mathrm{a}}$ \\
\hline Estradiol $17_{2 \alpha}(\mathrm{pg} / \mathrm{ml})$ & $27.12 \pm 0.82^{c}$ & $27.87 \pm 1.14^{\mathrm{bc}}$ & $29.19 \pm 1.22^{\mathrm{ab}}$ & $30.81 \pm 1.37^{\mathrm{a}}$ \\
\hline Progesterone (pg/ ml) & $0.714 \pm 0.031^{\mathrm{c}}$ & $0.729 \pm 0.037^{b c}$ & $0.798 \pm 0.041^{\mathrm{ab}}$ & $0.841 \pm 0.032^{a}$ \\
\hline
\end{tabular}

Means bearing different letter superscripts $(a, b, c)$ within the same row are significantly ( $\mathrm{p} \leq 0.05$ or 0.01$)$ different. 
Table (6): Fertility traits of Hy-Plus rabbit does fed diets with different levels of Doum

\begin{tabular}{|c|c|c|c|c|}
\hline \multirow{2}{*}{ Items } & \multicolumn{4}{|c|}{ Doumlevels (g/ Ton) } \\
\hline & $\begin{array}{c}(0.0) \\
\text { Control } \\
\end{array}$ & $\begin{array}{c}(250) \\
T_{1} \\
\end{array}$ & $\begin{array}{c}(\mathbf{5 0 0}) \\
\mathbf{T}_{2}\end{array}$ & $\begin{array}{c}(\mathbf{7 5 0}) \\
\mathbf{T}_{3} \\
\end{array}$ \\
\hline No. of inseminated does & 44 & 44 & 44 & 44 \\
\hline No. of pregnant does & 24 & 29 & 33 & 35 \\
\hline Conception rate $(\%)$ & $54.5^{\mathrm{d}}$ & $65.9^{\mathrm{c}}$ & $75.0^{\mathrm{b}}$ & $79.5^{\mathrm{a}}$ \\
\hline Abortion rate $(\%)$ & $4.5^{\mathrm{a}}$ & $2.3^{\mathrm{b}}$ & $00.0^{\mathrm{c}}$ & $00.0^{\mathrm{c}}$ \\
\hline No. of kindled does & 22 & 28 & 33 & 35 \\
\hline Kindling rate $(\%)$ & $50.0^{\mathrm{d}}$ & $63.6^{\mathrm{c}}$ & $75.0^{\mathrm{b}}$ & $79.5^{\mathrm{a}}$ \\
\hline Litter size at birth (No.) & $5.8 \pm 0.4^{\mathrm{c}}$ & $6.7 \pm 0.4^{\mathrm{b}}$ & $8.1 \pm 0.7^{\mathrm{a}}$ & $8.8 \pm 0.5^{\mathrm{a}}$ \\
\hline Bunny weight at birth(g) & $42.8 \pm 1.4$ & $42.3 \pm 1.9$ & $42.5 \pm 2.2$ & $41.9 \pm 1.7$ \\
\hline Litter weight at birth (g) & $248.2 \pm 21.2^{\mathrm{c}}$ & $283.4 \pm 20.9^{b}$ & $344.3 \pm 25.6^{\mathrm{a}}$ & $368.7 \pm 29^{a}$ \\
\hline Litter size at weaning (No.) & $5.0 \pm 0.3^{\mathrm{d}}$ & $6.1 \pm 0.4^{\mathrm{c}}$ & $7.8 \pm 0.3^{b}$ & $8.5 \pm 0.2^{\mathrm{a}}$ \\
\hline $\begin{array}{l}\text { Bunny weight at weaning } \\
(\mathrm{g})\end{array}$ & $694.2 \pm 21.3^{\mathrm{c}}$ & $758.3 \pm 24.7^{\mathrm{b}}$ & $801.6 \pm 24.4^{\mathrm{ab}}$ & $814.6 \pm 29.5^{\mathrm{a}}$ \\
\hline $\begin{array}{l}\text { litter weight } \\
\text { at weaning }(\mathrm{g})\end{array}$ & $3471.0 \pm 86.5^{\mathrm{d}}$ & $4625.6 \pm 93.1^{\mathrm{c}}$ & $6252.5 \pm 87.7^{b}$ & $6924.1 \pm 99.9^{\mathrm{a}}$ \\
\hline $\begin{array}{l}\text { Pre weaning } * * \\
\text { Mortality rate }(\%)\end{array}$ & $13.8 \pm 1.9^{\mathrm{a}}$ & $8.9 \pm 1.4^{b}$ & $3.7 \pm 0.2^{\mathrm{c}}$ & $3.4 \pm 0.2^{\mathrm{c}}$ \\
\hline
\end{tabular}

Means bearing different letter superscripts $(a, b, c, d)$ within the same row are significantly ( $\leq \leq 0.05$ or 0.01) different.

** Pre weaning mortality rate was calculated individually according to the following equation: Litter size at weaning - Litter size at birth / Litter size at weaning X 100 
Table (7): Milk yield (g) of Hy-Plus rabbit does fed diets with different levels of Doum (Means \pm SE)

\begin{tabular}{|c|c|c|c|c|c|}
\hline \multicolumn{2}{|c|}{ Period (Days) } & \multicolumn{4}{|c|}{ Doumlevels (g/ Ton) } \\
\hline From & To & $\begin{array}{c}(\mathbf{0 . 0}) \\
\text { Control } \\
\end{array}$ & $\begin{array}{c}(\mathbf{2 5 0}) \\
\mathbf{T}_{1} \\
\end{array}$ & $\begin{array}{c}(\mathbf{5 0 0}) \\
\mathbf{T}_{2} \\
\end{array}$ & $\begin{array}{c}\mathbf{( 7 5 0 )} \\
\mathbf{T}_{3} \\
\end{array}$ \\
\hline Birth & 7 & $454.6 \pm 27.2^{c}$ & $536.4 \pm 29.4^{\mathrm{b}}$ & $589.2 \pm 34.6^{\mathrm{ab}}$ & $611.7 \pm 33.0^{\mathrm{a}}$ \\
\hline 8 & 14 & $627.3 \pm 31.6^{\mathrm{c}}$ & $719.5 \pm 31.8^{b}$ & $785.4 \pm 35.2^{\mathrm{ab}}$ & $831.2 \pm 38.1^{\mathrm{a}}$ \\
\hline 15 & 21 & $761.2 \pm 34.3^{c}$ & $874.9 \pm 39.4^{b}$ & $963.8 \pm 38.4^{\mathrm{a}}$ & $1021.4 \pm 44.2^{\mathrm{a}}$ \\
\hline 22 & 28 & $542.9 \pm 28.4^{\mathrm{c}}$ & $631.7 \pm 30.3^{b}$ & $677.3 \pm 31.9^{\mathrm{ab}}$ & $701.5 \pm 37.5^{\mathrm{a}}$ \\
\hline 29 & 35 & $421.6 \pm 25.2^{\mathrm{c}}$ & $517.2 \pm 30.2^{b}$ & $565.3 \pm 30.8^{\mathrm{ab}}$ & $617.4 \pm 34.1^{\mathrm{a}}$ \\
\hline \multicolumn{2}{|c|}{ Total milk yield (g) } & $2807.6 \pm 72.9^{d}$ & $3279.7 \pm 84.0^{\mathrm{c}}$ & $3581.0 \pm 94.7^{b}$ & $3783.2 \pm 96.2^{\mathrm{a}}$ \\
\hline
\end{tabular}

Means bearing different letter superscripts $(a, b, c, d)$ within the same row, or $(a, b, c, d))$ within the same column are significantly $(\mathrm{p} \leq 0.05$ or 0.01$)$ different.

Table (8): Milk composition of Hy-Plus rabbit does fed diets with different levels of Doum, and naturally mated (Means \pm SE)

\begin{tabular}{|l|c|c|c|c|}
\hline \multirow{2}{*}{ Milk composition } & \multicolumn{4}{|c|}{ Doum levels (g/ Ton) } \\
\cline { 2 - 5 } & $\begin{array}{c}\mathbf{( 0 . 0 )} \\
\text { Control }\end{array}$ & $\begin{array}{c}\mathbf{( 2 5 0 )} \\
\mathbf{T}_{\mathbf{1}}\end{array}$ & $\begin{array}{c}\mathbf{( 5 0 0 )} \\
\mathbf{T}_{\mathbf{2}}\end{array}$ & $\begin{array}{c}\mathbf{( 7 5 0 )} \\
\mathbf{T}_{\mathbf{3}}\end{array}$ \\
\hline Milk Protein (\%) & $11.03 \pm 0.21^{\mathrm{b}}$ & $11.31 \pm 0.18^{\mathrm{b}}$ & $12.28 \pm 0.25^{\mathrm{a}}$ & $12.57 \pm 0.23^{\mathrm{a}}$ \\
Milk fat (\%) & $16.11 \pm 0.32^{\mathrm{c}}$ & $17.64 \pm 0.33^{\mathrm{ab}}$ & $17.89 \pm 0.31^{\mathrm{a}}$ & $18.34 \pm 0.33^{\mathrm{a}}$ \\
Milk lactose (\%) $^{\text {Milk ash (\%) }}$ & $3.78 \pm 0.06^{\mathrm{d}}$ & $3.99 \pm 0.08^{\mathrm{c}}$ & $4.38 \pm 0.08^{\mathrm{b}}$ & $4.57 \pm 0.09^{\mathrm{a}}$ \\
& $3.65 \pm 0.04^{\mathrm{c}}$ & $3.83 \pm 0.04^{\mathrm{b}}$ & $4.08 \pm 0.07^{\mathrm{a}}$ & $4.14 \pm 0.06^{\mathrm{a}}$ \\
\hline
\end{tabular}

Means bearing different letter superscripts $(\mathrm{a}, \mathrm{b}, \mathrm{c}, \mathrm{d})$ within the same row are significantly $(\mathrm{p} \leq 0.05$ or $0.01)$ different. 


\section{REFERENCES}

Abd El-Monem, U. M., 1995. Heat stresseffects and their amelioration on some traits under Egyptian summer conditions in Egypt. M. Sc. Thesis, Faculty of Agriculture, Zagazig University, Zagazig, Egypt.

Ali, W. A. H.; and Mervat, N. Ghazal, 2013. In vivo and in vitro studies on effect of Ganoderma on rabbit reproductivity, semen preservation and artificial insemination. J. Anim. Poult. prod., Mansoura Univ., 4(12): 715-731.

Ajagbonn, O. P.; Onifade, K. I.; and Suleiman, U., 1999. Heamatological and biochemical changes in rat given extract of Calatropisprocera. Sokoto J. Vet. Sci., 1: 36-42.

Baliga, M. S.; and Katiyar, S. K., 2006. Chemoprevention of photocarcinogenesis by selected dietary botanicals. Photochem. Photobiol. Sci., 5: 243-253.

Boiti, C.; Castellini, M.; Thau-Clément, M.; Besenfelder, U.; Liguori, L.; Renieri, T.; and Pizzi, F., 2005. Guidelines for the handling of rabbit bucks and semen. World Rabbit Sci., 13: 71-91.

Castellini, C.; Besenfelder, U.; Pizzi, F.; Theau-Clément, M.; Vicente, J. S. A.; and Renieri, T., 2006. Recent Knowledge on Rabbit Semen and Buck Management. (EU- Cost) Ed. Maertens L., Coudert, PP: 53-67.

Cogan, U.; Yaron, A.; Brek, Z.; and Zimmermen, G., 2004. Effect of processing condition on nutritive value of isolated soybean protein. J. Agric. Food Chem., 16: 196-198.

Cook, J. A.; VanderJagt, D. J.; Pastuszyn, A.; Mounkaila, G.; Glew, R. S.; Millison, M.; and Glew, H. R., 2000. Nutritional and chemical compositionof 13 wild plant foods of Niger. J. Food Comp. Anal. 13: 83-92.

Dawidowicz, A. L.; Wianoeska, D.; and Baraniak, B., 2006. The antioxidant properties of alcoholic extracts from Sambucus Nigra L. (antioxidant properties of extracts). Food Sci. Technol., 39: 308-315.

Di Carlo, G.; Autore, G.; Izzo, A. A.; Maiolino, P.; and Mascolo, N., 1993. Inhibition of intestinal motility and secretion by flavonoids in mice and rats: Structure activity relationships. J. Pharm. Pharmacol., 45: 1054-1059.

Dimitrios, B., 2006. Sources of natural phenolic antioxidants. Trends Food Sci. Technol., 17: 505-512.

Duncan, D. B., 1955. Multiple Range and Multiple (F-test). Biometrics, 11: 1-42.

Eiben, C. S.; Kustos, K.; Kenessy, A.; Virag, G. Y.; and Szendro, Z. S., 2010. Effect of different feed restriction during on production performance in rabbit does. World Rabbit Sci., 9(1): 9-14.

El-Kholy, K. H; El-Damrawy, S. Z.; and Seleem, T. S. T., 2012. Rabbit productivity and reproductivity as affected by cinnamon (Cinnamomum zeylanicum). Egypt. Poult. Sci., 32(6): 691-703.

EL-Maghawry, A.; Soliman, A. M.; and Khalil, H. H., 1993. Doe milk production as affected by some genetic and environmental factors in New Zealand White and Californian rabbits under the Egyptian conditions. Egypt. J. Rabbit Sci., 3(2): 141-150.

Elujoba, A. A.; Odeleye, O. M.; and Ogunyemi, C. M., 2005. Traditional medicine development for medical and dental primary health care delivery system in Africa. Afr. J. Trad. Complementary Altern. Med., 2: 46-61.

Fu-Chang, L., Qiu-Xia, L.; and Xiuling, Z., 2004. Comparative studies on growth performance, nutrient digestibility, immunity index and protease activities between weaning-2 month and 2-3 month New Zealand rabbits. In Proceeding: World Rabbit Congress, Puebla, Mexico, PP: 885-890.

Heinonen, M., 2007. Antioxidant activity and antimicrobial effect of berry 
phenolics - a Finnish perspective. Mol. Nutr. Food Res., 51: 684-691.

Hsu, B.; Coupar, I. M.; and Ng, K., 2006. Antioxidant activity of hot water extract from the fruit of the Doum palm, Hyphaenethebaica. Food Chem., 98: 317-328.

Hussein, A. S.; Alhadrami, G. A.; and Khalil, Y. H., 1998. The use of dates and date pits in broiler starter and finisher diets. Bioresource Technol., 66(3): 219-223.

Hussein, A. M. S.; Shedeed, N. A.; Abdel-Kalek, H. H.; and Shams ElDin, M. H. A., 2011. Antioxidative, Antibacterial and Antifungal Activities of Tea Infusionsfrom Berry Leaves, Carob and DoumPol. J. Food Nutr. Sci., 61(3): 201-209.

Katsube, T.; Tabata, H.; Ohta, Y.; Yamasaki, Y.; Anuurad, E.; and Shiwaku, K., 2004. Screening for antioxidant activity in edible plant products: comparison of low-density lipoprotein oxidation assay, DPPH radical scavenging assay, and folin ciocalteu assay. J. Agric. Food Chem., 52: 2391-2396.

Kilani, S.; Sghaier, M. B.; Limem, I.; Bouhlel, I.; Boubaker, J.; Bhouri, W.; Skandrani, I.; Neffatti, A.; Ammar, R. B.; Dijoux-Franca, M. G.; Ghedira, K.; and Chekir-Ghedira, L., 2008. In vitroevaluation of antibacterial, antioxidant, cytotoxic and apoptotic activities of the tubers infusion and extracts of Cyperus rotundus. Biores. Technol., 99: 9004-9008.

Lavaraa, R.; Mocéab, E.; Lavaraa, F.; De Castrob, M. V.; and Vicentea, J. S., 2005. The parameters of seminal quality correlate with the results of on-farm inseminations in rabbits. Cryobiology, 64: 1130-1141.

Lebas, F.; Coudert, P.; Rochambeau, H. De.; and Thébault, R. G., 1997. The Rabbit Husbandry, Health and Production. Food and Agriculture
Organization of the United Nations, FAO, Rome, Italy.

Mariey, Y. A.; Samak, H. R.; and Ibrahem, M. A., 2012. Effect of using spirulina platensis Algae as a feed additive for poultry diets: 1-productive and reproductive performance of local laying hens. Egypt. Poult. sci., 32(1): 201-215.

NRC, 1977. National Research Council. National Academic of Sci. Washington, D. C. USA, $30 \mathrm{p}$.

Petersen, J.; Hartman, J.; and Mennicken, L., 1996. Effect of prenatal on postnatal performance of does. Proc. $6^{\text {th }}$ World Rabbit Cong. Toulouse, 2: 103-106.

Pesewu, G. A.; Cutler, R. R.; and Humber, D. P., 2008. Antibacterial activity of plants used in traditional medicines of Ghana with particular reference to MRSA. J. Ethnopharmacol., 116: 102-111.

Qureshi, M. A.; Kidd, M. T.; and Ali, R. A., 1995. Spirulina Platensis extract enhances chicken macrophage functions after in vitro exposure. J. Nutr. Immunol., 3(4): 35-45.

Rommers, J. M.; Meijerhof, R; Noordhuizen, J. P. T. M.; and Kemp, B., 2001. Effect of different feeding levels during rearing and age at first insemination on body development, body composition and puberty characteristics of rabbit does. World Rabbit Sci., 9: 101-108.

Safaa, A. Barakat; and Rowida, M. Riad, 2016. Effect of Doum(HYPHAENE THEBAICA) ${ }^{\circledR}$ on response of rabbit spermatozoa to Hypo-osmotic swollen test. Egypt. J. Rabbit Sci. (In Press)

Sanchez-Moreno, C.; Larrauri, J. A.; and Saura-Calixto, F., 1999. Free radical scavenging capacity and inhibition of lipid oxidation of wines, grape juices and related polyphenolic constituents. Food Res. Int., 32: 407412. 
SAS, 2001. Statistical Analysis System, User's Guide Version 8.2 Cary NC. USA

Schalm, O. W; Jain, N. C.; and Carroll, E. J., 1975. Veterinity haematology . USA: Lea and Fabiger, Philadelphia. $3^{\text {rd }}$ Ed., Lea and Febiger, Philadelphi, PP: 340-370.

Snedecor, G. W.; and Cochran, W. G., 1982. Statistical Methods. 2nd Ed. Iowa University, Press Ames, Iowa,USA.

Szendro, zs.; Randai, I.; BironeNemeth, E.; Romvari, R.; and Milists, G., 2002. Effect of live weight on the carcass traits of pennon white rabbits. 3rd Int. Symp. "Animal Science Days", Sept. 26-29, 1995, Bled, Slovenia.

Tasdelen, F. N.; Tanriverdi, C. Y.; Coban, A. Y.; Ozatli, D.; Tanyel, E.;
Durupinar, B.; and Tulek, N., 2009. Antimicrobial activity of plant extract Ankaferd Blood Stopper. Fitoterapia., 80: 48-50.

Togun, V. A.; and Egbunike, G. N., 2006. Seasonal variations in the sperm production characteristics of Zebu (White Fulani) cattle genitalia in the humid tropical environment. MiddleEast J. Sci., 1: 87-95.

Warren, J. E.; and Gregory, G., 2005. Statistical Methods in Bioinformatics: An Introduction (Statistics for Biology and Health). Springer Science press, New York, USA.

Yang, J. H.; Lin, H. C.; and Mau, J. L., 2002. Antioxidant properties of several commercial mushrooms. Food Chem., 77: 229-235.

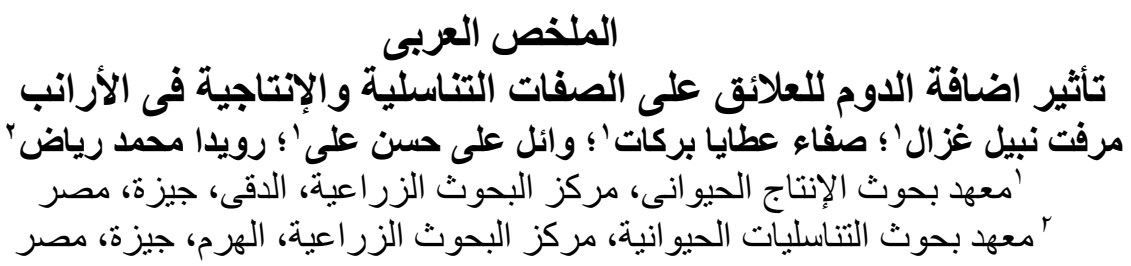

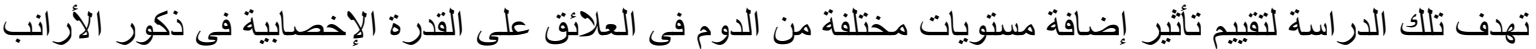

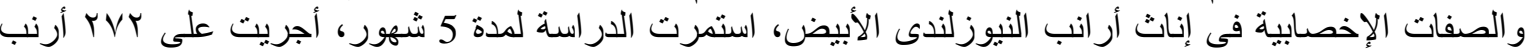

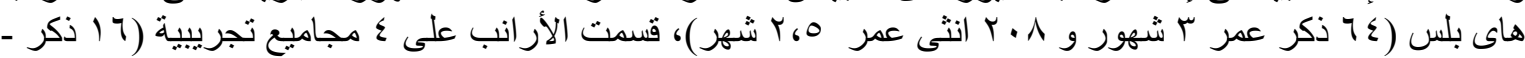

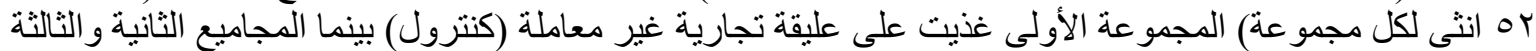

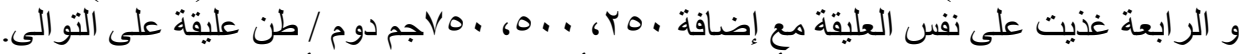

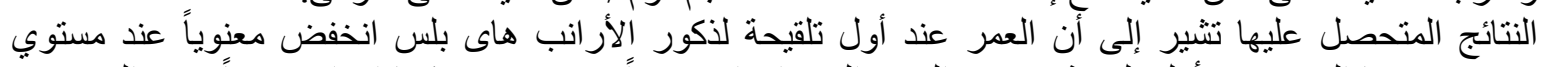

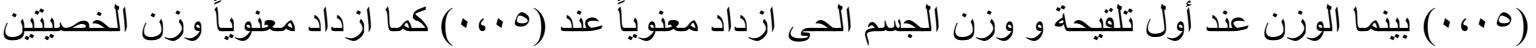

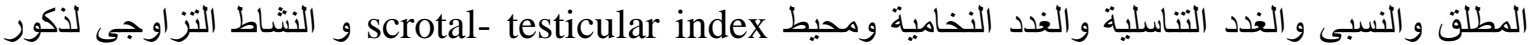

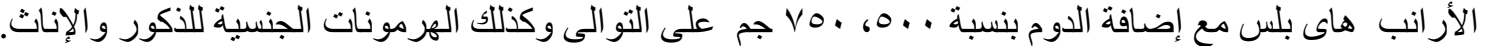

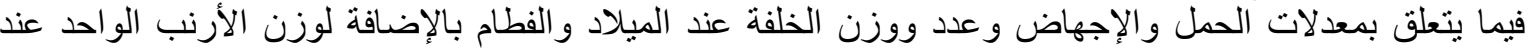

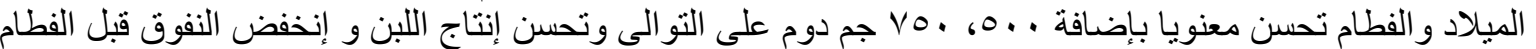

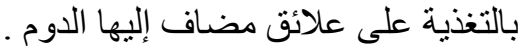

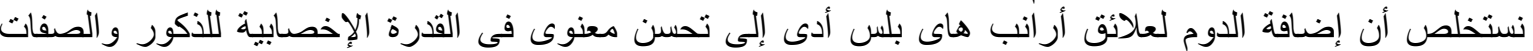

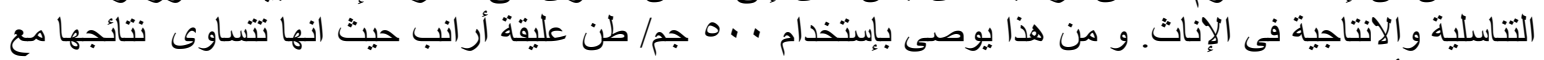
المعاملة الأعلى. 